\title{
The Human Crocodile Conflicts and the Sustainable Conflict Resolutions Review
}

\author{
Chakuya Jeremiah ${ }^{1 *}$ and Gondo Reniko ${ }^{2}$ \\ ${ }^{1}$ Chakuya Jeremiah School of Wildlife, Ecology and Conservation, Chinhoyi University of Technology, Private Bag 7724 Chinhoyi, Zimbabwe
}

${ }^{2}$ Okavango Research Institute, University of Botswana P/Bag 285, Maun, Botswana

Submission: June 29, 2018; Published: July 09, 2018

*Corresponding author: Jeremiah Chakuya, Chakuya Jeremiah School of Wildlife, Ecology and Conservation, Chinhoyi University of Technology, Private Bag 7724 Chinhoyi, Zimbabwe, Email: jchakuya@gmail.com

\begin{abstract}
The survival of Nile crocodiles in both protected areas and communal areas has been associated with an increasingly uncertainty due to a combination of natural and anthropogenic threats. In this regard sustainable conservation methods are highly recommended in as far as Human and Crocodile Conflicts (HCC) are concerned. Anthropogenic activities are viewed as potential threat to crocodile survival and some people in turn see crocodiles as dangerous problem animals to their activities. The traditional HCC resolutions have been blamed for increasing attacks on humans and livestock resulting in decreased local support for conservation initiatives hence the need to have satisfactory and effective HCC resolution. The review pointed out that little work has been done on the sustainable management of Nile crocodiles especially for the benefit of those who bear the costs of living with them. The review investigated the main causes of the HCC and identified sustainable conservation strategies which enhance the well-being of humans and Nile crocodile. The paper explores sustainable HCC resolution which can be implemented by Wildlife Managers and communities. The study made several recommendations to conservationist and respective authorities on HCC conflict mitigation. The study showed enough economic evidence which suggests that the value of Nile crocodiles could offset the HCC provided that the Nile crocodile population is managed and exploited in an ecologically and socially sustainable manner. In this regard sustainable HCC resolution could also be employed as a valuable tool in poverty alleviation and freshwater conservation as well as other habitat conservation..
\end{abstract}

Keywords: Crocodile; Human Conflict; Resolution; Sustainable

\section{Introduction}

Nile crocodile survival is threatened by pollution, extensive water extraction for irrigation and domestic use, over harvesting of fish and this has led to a rise in human crocodile conflicts [13]. The loss of habitat and food shortage has increased humans and livestock predation by Nile crocodile [4]. In most case human crocodile conflicts arises as fishermen and livestock farmers retaliate by damaging Nile crocodile nest and eggs as well as killing them in an attempt to reduce or eradicate them [5]. The disturbance of the Nile crocodile ecology results in competition thus increase in human crocodile conflicts (HCC). The study explores the challenges in Nile crocodile conservation and suggests sustainable HCC resolution. Studies in Philippines revealed that river usage through fishing and transport has resulted in constant attrition of crocodiles killing to the extent of virtual disappearance of two crocodile species (CSG, 2004). In Madagascar it was noted that rural people are often intolerant and Nile crocodile suffer deliberate nests and habitat destruction. In the case of Zimbabwe's Lake Kariba, fluctuations in water level due to agricultural or hydroelectric demand have affected reproduction of crocodiles in impoundments. Crocodile mortality by people, directly or indirectly, both deliberate and inadvertent, must be controlled and this forms the core of this study. Conservation of crocodilian populations is therefore highly dependent upon providing incentives to maintain crocodiles and their habitats in a relatively undisturbed state, and a willingness to accept management practices that allow crocodiles and humans to co-exist. Papua New Guinea uses hen eggs and a cash price to pay local villagers who protect nesting female crocodiles as a valuable resource (CSG, 2004) and this plays a pivotal role in ensuring co-existence.

The Crocodylusniloticusis commonly known as Nile crocodile, Mamba (Swahili), Garwe (Shona), Ngwenya (Ndebele). Nile crocodiles are mainly conserved through the CITES Appendix system (CSG, 2004). Nile crocodiles are found in appendix II in Zimbabwe, Tanzania, Zambia, Botswana, Ethiopia, Kenya, Malawi, Mozambique and South Africa (Figure 1) due to the ranching criteria which they have adopted [6]. Uganda and Madagascar still use the quota systems whereas the rest of Africa in which Nile crocodiles are found is in. The responses of the Zimbabwe population to prolonged sustainable harvest are also well studied. Nile crocodiles can be harvested through Problem Animal Control (PAC), trophy hunting harvested for their skins and meat (UNEP- 
WCMC, 2008) and this can be evidenced by 11551 CITES permits which were issued to Namibia in 2005. HHK Safaris, (2008) confirms that foreign clients pay up to US $\$ 3000$ to shoot a single Nile crocodile and Namibia is estimated to generates at least US\$19.6 million through trophy hunts and this money goes a long way in improving the lives of the local people (Humavindu
\& Barnes). Studies in Venezuela by Thorbjarnarson \& Velasco, revealed that sustainable crocodile harvest reduced HCC at the same time bringing foreign earnings in excess of US $\$ 115$ million as large crocodile which posed threat to humans and livestock were harvested or removed as problem animals (Kofron).

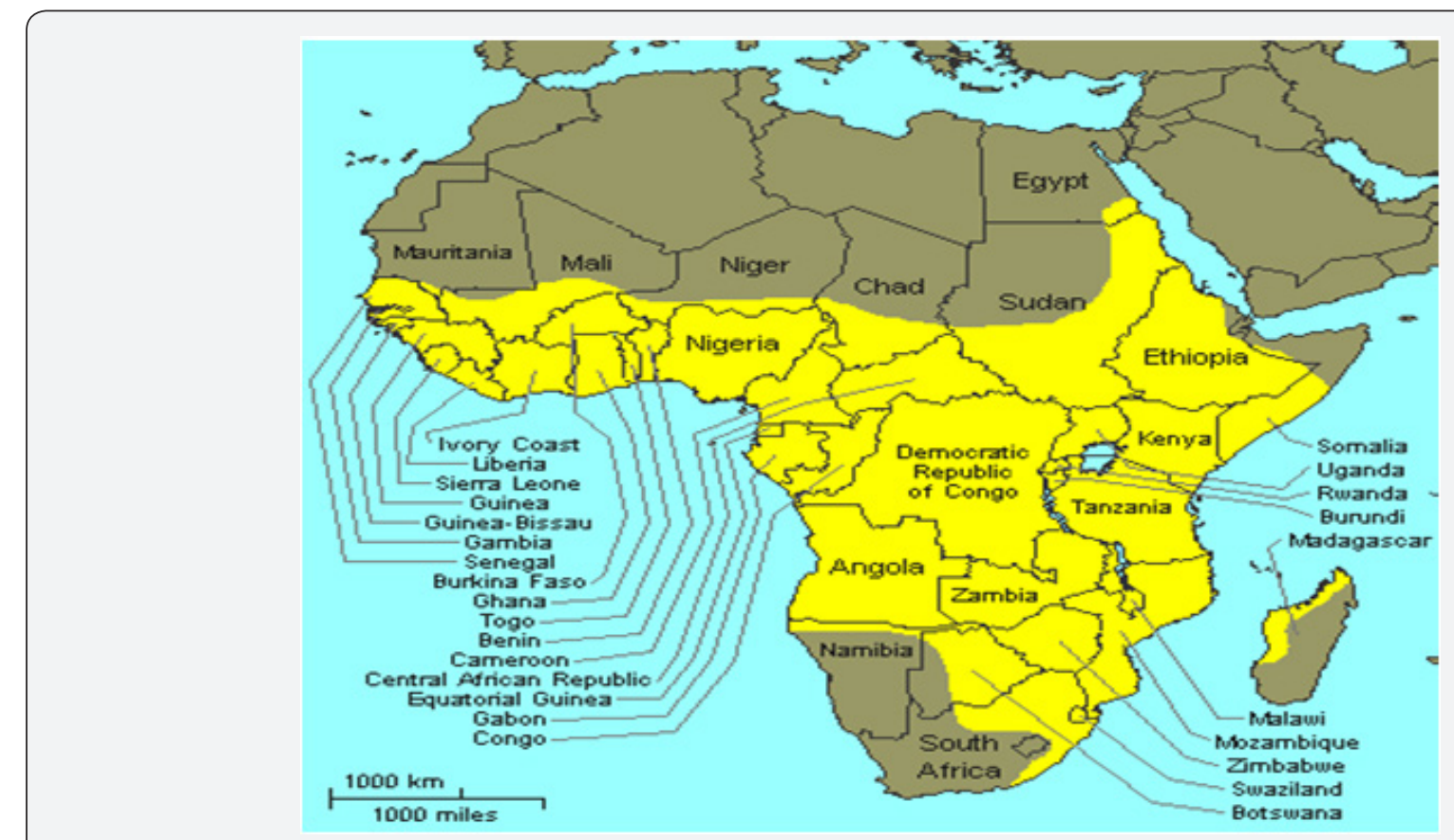

Figure 1: Yellow indicates the present distribution of Nile crocodile in Africa. (Source: Fergusson, 2010).

To date there are still so many African countries which are facing challenges to ensure sustainable utilization of wild Nile crocodiles since there are very limited licensed enterprises and communities receive very little direct benefits from Nile crocodiles which they blame as problem animals. In response to the above matter, Stearman suggests that researches on management plans should be directed to the biological and social complexities which affect effective exploitation of natural resources. Ecotourism is one of the solutions which were found to help generate income which can offset the cost of wild Nile crocodile conservation. Thorbjarnarson [7] postulates that there are thirteen documented crocodilian species, out of these species, Nile crocodile ( $C$. Niloticus) is widespread in the African continent and it is of concern in as far as HCC are concerned. Nile crocodile were very common throughout Africa and the Middle East in the 20th century before serious land fragmentation and illegal killing [8]. The decline of crocodile was mainly caused by uncontrolled hunts for crocodile hides, meat and medicinal purposes $[8,9]$. Currently the Nile crocodile global population is estimated to be $250,000-500,000$ animals and this is also supported by crocodile farming [10]. Despite all climatic and global ecological changes, Nile crocodile are still found in countries like, Cote d"Ivore, Zambia, Zimbabwe, Botswana, Ethiopia, Kenya, Egypt, Gabon, Ethiopia and South Africa (Figure 1) and still poses conflicts with humans.
The Nile crocodile is a keystone species and its conservation help to maintain aquatic ecology which helps in maintaining healthy ecosystems and this goes a long way in the conservation of wetland biodiversity [11]. In this regard, HCC needs to be managed well if possible sustainable methods needs to be devised in conflict resolution. Crocodile exploitation in Africa dates back in the eighteenth century when Europe was undergoing the Industrial Revolution. The scale of Nile crocodile exploitation in Africa was uncontrolled, approximately 60000 Nile crocodile skins were exported from East Africa in the mid 1950 [12], on the other hand nearly 40000 skins were harvested and exported from Botswana alone between 1956-1977 (Cott \& Pooley).

\section{Map of Africa Showing Areas with Nile Crocodiles}

Lack of fundamental understanding could has led many conservationists to regard Nile crocodile as a pest which can best be controlled by elimination or removal from an area. This can be evidenced by Uganda's programmes of 1930 and 1950s which resulted in the destruction of approximately 1500 to 2000 female crocodile nests and this resulted in the serious decline in Nile crocodile population Gans. Observations from the catastrophic Nile crocodile population crashes led to the rise of conservation movements around 1970s which led to the formation of National laws which were further backed up by international laws like CITES. In 1975 Nile crocodiles were listed in the CITES appendix 
I and this greatly helped the further decline of Nile crocodile population. Law enforcement and compliance to the CITES regulation by many African countries led to the need of sustainable use of Nile crocodiles. Caldwell confirmed that the annual world trade of all crocodilian species is estimated at 1.3 million skins. Due to the decline in the supply of wild Nile crocodile skins on the international market this led to the formation of crocodile farms and ranches to cater for the demand. Ross et al. [12] define crocodile ranching as a farming practice which involves collection of wild crocodile eggs and even a small number of young crocodile for rearing while crocodile farming involves the captive breeding and rearing of crocodiles. However crocodile farming and ranching has been subject to criticism by some conservationist as these methods are alleged to fail to demonstrate sustainable conservation of wild Nile crocodile. However, the IUCNs Crocodile Specialist Group regards crocodile ranching as an economically viable conservation method (CSG, 2004) and this can be evidenced by the vast majority of subsistence communities living alongside crocodiles seldom benefit directly from these operations.

\section{Literature Review}

Crocodile Ecology, Characteristics and Behaviour: Crocodile are classified under reptiles, have been noted as dangerous animals when they reach maturity and they are regarded to have no predators of their own. They are carnivores, gregarious, depending on food availability, cold blooded and bask for the sun to improve their temperature $[12,13]$. Crocodile gain energy from the sun for digestion; hunting and they can hibernate for up to two years without food (Walsh). Crocodiles have good eyesight both during day and night armed with sharp teeth which makes its hunting easy. Nile crocodile start reproducing at the age of between 10 and 12 years with males growing faster than females [14]. Temperature play a pivotal role in the Nile crocodile ecology as it determines the growth rate, the sex of the crocodile at hatching and the feeding behaviour (Lang \& Andrews, 1994). Nile crocodile usually mate in the late winter between July and August and one male can mate with several female and the eggs are laid in September. They lay their eggs adjacent to the river or water source for easy monitoring of raptors such as hyenas, birds and lizards. A single clutch laid may have 25 to 80 eggs in an approximately 0.5 metre deep hole and the female frequently urinates or splashes water on the nest to maintain temperatures [15]. Nile crocodile eggs takes about 90 days to incubate and depends on the temperature range between $28^{\circ} \mathrm{C}$ and $34.5^{\circ} \mathrm{C}$, temperature below or above no hatchling will survive [14]. Favourable temperature and food availability in November and January could be the explanation why there is high Nile crocodile eggs hatching.

\section{Crocodile Prey and Hunting Strategies}

Nile crocodiles have a wide range of prey from natural ecosystem which may comprise of insects, small aquatic invertebrates and larger vertebrates, as they grow, impala (Aepycerosmelampus) to buffalo (Synceruscaffer) among others
$[16,17]$. Their diet constantly changes with the age and fully grown crocodiles feed on larger prey. However with the increase in human population and land fragmentation, crocodiles shifted their preferred natural species to domestic animals. ScheiessMeier et al. [18] notes that Nile crocodiles resort to livestock and humans to substitute for their natural prey which was affected by land fragmentation. Studies by Dikobe [19] reviewed that Nile crocodiles easily prey goats (Capra hircus) and cattle (Bosindicus) in wet seasons since natural prey will be scarce.

\section{Nile Crocodiles' Hunting Behavior}

Nile crocodiles are opportunistic feeders and they use the common strategy of remaining silent in murky coloured water, and they detect movement prey by the sensory pits along the sides of the jaws and also by smell [20]. Gruen [21] confirms that crocodiles can lie in still waters, leaving their eyes; nostrils and ears out and catch prey which comes within the two-metre radius, drags and suffocating the prey under water. They usually use the surprise attacks to its prey and this could be to easily suffocate bigger prey. Observations from Matusadona national park indicated that some lions preyed on crocodile and this is very rare.

\section{Human Compromising Activities with Nile Crocodile}

Fishing Using the Traditional Artisanal Gear: Fish in most communal areas is managed by common property norms and there are no security measures to scientifically manage fishing. Scientific management helps to regulate fishing and this helps to know the quantity yielded per year thus helping setting sustainable quotas [22]. The traditional artisanal gear involves the use of rod and line and people may fish from the banks or fish while standing in water. The hook and rod method is mainly effective in areas where there is high water content like in dams and rivers and targets bigger fish. These methods are cheap and in most case are not licensed and this results in over harvesting of fish wish end up compromising with the food chain in the ecosystem where there will be crocodiles. Apart from that, there is the use of scoop nets, plastic bottle trap, and the cast net among others which are used to harvest fish. These methods are mainly designed to restrain the fish from escaping and are effective in catching small fish in areas with limited amount of water. These methods expose fishermen to crocodile attacks as they will be very close to water during fishing.

The Use of Gillnets: The use of gillnets is common in most of the countries in southern Africa and is licensed and these licenses are renewed annually. The scientifically managed use of gillnets controls the mesh size and the fish size as well as the total fish to be harvested annually. Since fish and water is regarded as a common property, people in communal areas resorted to the use of sacks, mosquito nets and shore seines to catch fish [22]. These methods involve extraction of all fish in both small reservoirs and dams, due to their un-sustainability these methods result in over harvesting of food to the crocodile and this raises the HCC. Apart from that the methods they use exposes them to crocodiles attack as it involves constant movements in water. 
Seine Netting: Commonly practiced in Zimbabwe and Zambia and it is very dangerous, involves a team of three or four fishermen wading waist deep through deep pools, swimming and diving to flush fish from their hiding places while gradually pulling the net closed. Fishermen carry knives to defend them from crocodile as they constantly disturb crocodile habitats and food. As can be observed, people expose themselves to the risk of crocodile attacks. Fishermans who prefer the use of this method regard Nile crocodile as pest which needs to be removed in rivers such that their interest could be protected [23].

\section{Nile Crocodiles Attacks on Humans and Domestic Animals}

People in rural areas have to make use of natural water bodies for domestic water, washing clothes and bathing. As a consequence of this, many people are exposed almost daily to the risk of being attacked by a crocodile [17]. Musambachine [23] confirms that the Nile crocodile is considered as most dangerous species of crocodile, and is responsible for many human deaths. Humans could be attacked as crocodile defend their territories. Breeding Nile crocodile females are defensive and they attack any predator which tries to come close to their nets and young ones and most fishermen get easily attacked by such crocodiles. Apart from that, crocodiles are opportunity feeders and humans can be accidentally attacked if they come across the path of hunting crocodiles. Domestic animals are easily preyed by crocodiles in the dry season since dams, river and water logged areas will be only sources of water. Whitlow [24] confirms that, wetlands will be waterlogged during rainy seasons, which make them good sources for green pasture for grazing domestic animals and this makes them prone to crocodile attacks. Domestic animals graze on banks of rivers and dams, where green pasture always exists. This is worsened by increased fishing and general human presence around the water source and leads to continuous human encroachment into crocodile areas; hence disturbance to crocodile sites, and furthermore reduced fish stock attributed to water pollution results in negative effects on crocodile thus a rise in HCC.

\section{Managing Human and Wildlife Conflict}

Human and Wildlife Conflict (HWC), as well as Human Crocodile Conflict (HCC), are complex, which requires simple, mutual inclusive approaches for the continued existence of both humen (and their livelihood) and the so-called problem animal [25]. The management plan should be designed in accordance with traditional rules operating in the area [26]. With the local people formulating, administering and managing the strategies that ensures the chances for survival of threatened species. This has led to the growth of Community Based Natural Resource Management (CBNRM) programmes in Africa [27].

\section{Compensation}

Compensation should be given for every fatal incident that has been caused due to crocodiles however prior assessment of the damage needs to be done, to avoid over-compensation and exaggeration of the incident by the affected people [25]. Compensation can be in monetary form, or replacing of the killed livestock animal - though this method is ineffective, due to the budgetary constraints of developing countries [25]. The payouts are poor, or too small to equate the damage or loss to an individual property. The system of compensating might be poor, leaving affected individuals not benefitting from it. In India, many processes are involved - which are costly and timeous, hence claiming for losses has become unpopular [28]. This was also found in Kenya, where pay-outs for losses are low [29]. Problems may only arise when human life has been lost, as money cannot be equated with life. Non Governmental Organisations have made efforts in communities in Africa like in Namibia to financially compensate livestock lost through crocodile attacks. This scheme faced technical challenges in the methods to use in assessing the proof of livestock loss from individuals, insufficient funds and the long-term viability was unsustainable.

\section{Physical Barriers}

The use of barriers, also known as Crocodile Exclusion Enclosures (CEE), works well when in combination with crocodile disturbance, and more effectively, when problem sites have been identified as in Sri Lanka [30]. The modern CEEs are similar to enclosures used at crocodile farms. Barriers include the erection of fences, packing of thorny branches and rocks in frequently used sites for bathing, washing clothes and house utensils. Danger warning signs, showing safe places, should be shown on entry points, and also how the CEE works [31]. The CEE gate should always be kept closed, whether in or out of use [30]. The noise made by humans will continuously affect the activities of the predator, reducing chances of depredation. Ecologically this might negatively affect the crocodile population, as the nesting sites are affected, and breeding rates will decrease.

\section{Problem Crocodile Control (PCC)}

Problem crocodiles control should be conducted under the guidance from specialized staff for example in Zimbabwe there is Parks and Wildlife Management Authority (PWMA) and professional guides or hunters. This is only effective if the PCC does involve shooting and killing of the right identified crocodile in the area. When innocent animals are mistakenly identified, it becomes expensive as the procedure need to be repeated to cater for correct animal. PCC can involve translocation (in-situ to exsitu) or 'wild to wild', if unoccupied habitats exists, due to their social behaviour, although 'wild to wild' remains a problem as crocodiles normally return to their original habitat [22]. Permits granted to community-based ranger groups should only allow live capture of crocodiles and selling off them to crocodile farmers [31]. If crocodiles are moved from 'wild to wild' where other crocodiles exist, they may suffer physical damage and predation, as they fight for control of territory and limited resources [32,33]. For successful PCC, effective communication links between governments, stakeholders, conservation groups and community 
and proper monitoring, and awareness campaigns about dangers and the importance of predators should properly carried out [34,35].

\section{The Main Sources of Human and Crocodile Conflicts}

Chenje noted that there was a growing demand of fresh water in Africa for agricultural, industrial and domestic use and this has resulted in disruption of fresh water ecosystems along water sources due to increase in human population. As human population increased along the fresh water sources, the incidences of humans' attacks by crocodiles were observed to be positively correlated. Although Nile crocodiles are regarded as efficient colonisers and resistant to human environmental degradation, they still kill livestock and people especially if their natural prey base is destroyed Apart from that, Nile crocodiles especially in communal areas they compete with humans for fish. Unsustainable population of Nile crocodiles in small rivers and dams prey on many economically important fish species thus living the community with nothing to admire from these crocodiles (Wallace). Games \& Moreau [6] argues that Nile crocodile are beneficial in the ecosystems of fresh water as they eat more significant fish predators like water birds. However the fact that Nile crocodiles destroy valuable fishing equipment and interfere with fishing efforts cannot be debated and this ignites the sources of HCC. Nile crocodiles destroy fishing gears as they feed on the trapped fish and sometimes disrupts the casted nets as they move within the water (McGregor). The delays by respective authorities for example Zimbabwe Parks and Wildlife Management Authority to ameliorate these problems will result in worst retaliation by the communal people who live along with these Nile crocodiles. Humans and Crocodile Conflict Resolution.

Reducing the Risk of Crocodile Attacks: In most of the investigations carried out on people who are attacked by crocodiles, many people take little or no precautions when collecting water or washing in the rivers or dams [36]. Some could take necessary precaution but crocodiles are patient hunters and they conceal themselves and know the best time to attack. Fenced enclosure acts as an immediate solution to protect villagers and local communities who use river and dam water from crocodile attack [36]. These enclosures can be made using diamond mesh wires, barbed wire, wood or any obstacles which can prevent entry of crocodile to where people regularly use water. These enclosures should be at least two that is the one to cater for normal and low river levels and the other for river high levels of a dam or river.

\section{Protective Barriers}

Government or responsible authorities can assist the local communities with wire netting which will be needed to build enclosures (Aust, [36]). Areas of rivers or dams which are known to have very high risk of crocodile attacks to humans and livestock can be erected wire barriers which exclude crocodiles. People and their livestock should be discouraged to use other points which are not protected by such barriers. In some cases these barriers can be made from timber and hand woven nets. Zimbabwe Parks and Wildlife Management Authority can set aside some exclusion areas for tourist who may want to use the water sources for swimming. Lake Kariba is one of the resort areas without exclusion areas for swimming as there are dangerous crocodiles and hippopotamus. Wangi Falls in Litchfield National Park has these exclusion area and they help reduce crocodile attacks to tourist (Aust, [36]). There is a risk that sometimes these crocodiles may break exclusion barriers into exclusion areas however to reduce that swimming exclusion areas should firstly be surveyed and find if there are crocodiles. If crocodiles are found within exclusion area, they can be trapped, harpooning, removed or shot in extreme cases, warning signs can be installed and the public is notified of the dangers of swimming in such water. However the exclusion barriers proved to be ineffective in the Chobe River due to the constant water fluctuation coupled with hippopotamus damage on the erected wire mesh [36].

\section{Awareness Training}

Tourist and communities which lives with crocodiles should be made aware of the crocodile habitat, territoriality, hunting strategies and biology. Awareness educates the public of the crocodile breeding seasons and this knowledge helps people to know how, when and why crocodiles attack humans and this goes a long way in preventing further human attacks by crocodiles [36]. Awareness training may include the precautions to be taken to avoid an attack, and what best to do if one is attacked. Information for awareness can be communicated over the radio during the hot season when Nile crocodile attacks are most common, by posters in schools and warning signs near the water sources.

\section{Use of Wells Instead of Direct Water from the River or Dam}

Crocodiles spend long time monitoring all movements at the water sources as a hunting strategy [36]. Women and children who regularly fetch water and bath are easily preyed by hunting crocodiles. In this regard villagers can be encouraged to dig wells close to rivers so that water can be collected safely.

\section{Lifting Water Out of the River or Dam}

Some parts of river banks or dams may be very difficult to construct enclosures or barriers; villagers may construct simple water lifting devices like Egyptian "shadoof". Steep sides of rivers or banks poses a serious risk to humans and livestock as it will be difficult to detect hidden crocodiles and deep waters allows crocodiles to easily kill their prey through suffocation.

\section{Establishment of Public/Individual Bathing Facilities}

Government or NGO can assist the local villagers who lives closer to river and dams to install water tanks, solar powered motor and ablution blocks for bathing. Male and female bath rooms build away from the river or dams reduces the risks of human attacks by crocodiles as people will not come closer to the hunting crocodiles. This approach is very useful during severe drought periods when the CEE will be unusable. 


\section{Construction of Bridges for Safe Crossing}

In most communal areas people crosses rivers or parts of dams on foot or by boats or small rafts and this poses people at risk to crocodile attacks. The government or NGOs can work to increase access points especially to areas which are frequently used. In some cases, local communities should be discouraged to cross flooded rivers.

\section{Reducing Crocodile Numbers in an Area}

Sustainable conservationist argues that it is not logical to have crocodile populations in rivers or dams where there is not enough natural food to support large crocodiles. There is still a debate among other ecologist on the idea of capturing and removing some excess crocodiles alive to be used in the crocodile farming [36]. Ecologists' main argument basis on the fact that the removal of crocodiles from a river will disrupt the ecology of the river system since they are apex predators. However such ecologist and other conservationist must take into account that most rivers are no longer pristine natural systems due to pollution and contamination by alien and invasive fish and plants species and the construction of dams in the catchments affected the natural flow regimes for example the Kariba, Cahora Bassa and the Kafue dams. Apart from that, hippos have been eliminated in most of the rivers and dams in rural areas and these hippos were important in opening channels through the reeds in a river system. Most hippos are found in a river which passes through protected lands. Basing on these facts, the removal of crocodiles from selected sites within a river will not have a measurable ecological impact on the rivers. Studies have revealed that crocodiles caught by trapping or harpooning and translocated into farms or other protected areas, satellite tracking have shown that such crocodiles move hundreds of kilometres to return to locations from which they were removed. Relocating crocodiles into the wild is viewed by other conservationist as an ineffective way of managing problem crocodiles [36].

Crocodile numbers can be reduced through the use of CITES permits to hunt a certain quota of crocodile and the money could be used for community beneficiation. For example Mozambique got 100 crocodiles for trophy hunting. Live capture of crocodiles from the rivers to be used as breeders can be done in farms. Apart from that some crocodiles could be captured and trans-located to other places where they pose less danger to human life and livestock. The Problem Crocodile Control (PCC) this has been noted as another measure of reducing the numbers of crocodiles which terrorises people. This may involve the shooting or caging the crocodile and then kill it. However this technique raises lots of debate on the criteria used to determine the exact problem crocodile considering that some crocodiles may be so many on a small area [37-44].

\section{Conclusion}

Nile crocodile are prominent and economically important component of the fresh water ecosystem in southern Africa.
Managing crocodiles is a complex task that requires findings balance between competing economic uses and conservation. Sustainable conservationist suggest that crocodile populations in rivers or dams should be well supported with food availability and this resulted in the use of CITES permits to hunt problem crocodiles and an annual quota to maintain the carrying capacity and community beneficiation. Erecting exclusion barriers and public awareness campaigns goes a long way in reducing the HCC.

\section{Acknowledgment}

This work did not get specific funding but it got support from the authors' employer The Zimbabwe National Parks and Wildlife Management Authority in the form of permission and vehicles in carrying the survey in the fishing camps. This work was part of authors' employment requirements. The authors thank $\mathrm{Mr}$ Kupamupindi, Makwangwari and Wildlife Rangers helpful discussions.

\section{References}

1. Botha PJ (2010)The distribution, conservation status and blood biochemistry of Nile crocodile in the Olifants River system in Mpumalanga, South Africa. PhD Thesis. University of Pretoria.

2. Shirley MH, Oduro W, Beibro HY (2009) Conservation status of crocodiles in Ghana and Cote-d"Ivore, West Africa. Fauna and flora international43(1): 136-145.

3. Okello MM, Ole Seno SK, Nthiga RW (2009) Reconciling peoples livelihoods and environmental conservation in the rural landscapes in Kenya: opportunities and challenges in the Amboseli landscapes. Natural resources forum 33(2): 123-133.

4. Conover MR (2002) Resolving human-wildlife conflicts: the science of wildlife damage management. Boca Raton

5. Shacks V (2006) Habitat vulnerability for the Nile crocodile (Crocodylusniloticus) in the Okavango Delta, Botswana. MA dissertation. University of Stellenbosch.

6. Games I, E Severre (1992) The status and distribution of Crocodiles in Tanzania. In: Crocodiles, Proceedings of the $11^{\text {th }}$ Working Meeting of the Crocodile SpecialistGroup 1:119-137.

7. Thorbjarnarson JB (1996) The reproductive characteristics of the Order Crocodylia.Herpetologica. 52(1): 8-24.

8. Whiting MJ, Williams VL, Hibbitts TJ (2011) Animals traded for traditional medicine at the Faraday market in South Africa: species diversity and conservation implication. Journal of zoology 284: 84-96.

9. Thorbjarnarson J (1992) Crocodiles: An Action Plan for their Conservation. IUCN pp. 128-136.

10. Hekkala E, Shirley MH, Amato G, Austin JD, Charter S, et al. (2011) An ancient icon reveals new mysteries: mummy DNA resurrects a cryptic species within the Nile crocodile. Molecular ecology 20(20): 14994215.

11. Sergio F, Caro T, Brown D, Clucas B, Hunter J, et al. (2008) Top predators as conservation tools: ecological rational assumptions and efficacy. JSTOR journal 39: 1-19.

12. Ross JP (1998) Crocodiles Status Survey and Conservation Action Plan. $2^{\text {nd }}$ Edition.IUCN/SSC Crocodile Specialist Group. IUCN, Gland, Switzerland and Cambridge, UK.

13. Seebacher F, Grigg G, Beard L (1999) Crocodiles as dinosaurs: Behaviouralthermoregulation in very large ectotherms leads to high 
and stable body temperatures. Journal of experimental biology 202(1): 77-86.

14. Hutton JM (1989) Movement, home range, dispersal and separation of size classes in Nile crocodiles. American Zoologist 29(3): 1033-1049.

15. Jelden D, Games I, Rosser A (1994) Crocodile Management in Tanzania. Summary report of an IUCN/ SSC Crocodile Specialist Group mission to Tanzania. Mimeo report:31.

16. Wallace KM, Leslie A (2008)The diet of the Nile crocodile (Crocodylusniloticus) in the Okavango Delta, Botswana. Journal of herpetology 42(2): 361-368.

17. Anderson JL, Pariela F (2005) Strategies to mitigate human-wildlife conflicts Mozambique FAO.

18. Scheiess-Meier M, Ramsauer S, Gabanapelo T, Kong B (2007) Livestock predation-insight from problem animal control registers in Botswana. Journal of wildlife management 71(4): 1267-1274.

19. Dikobe ML (1997) Patterns and economic impacts of livestock predation in rural communities bordering Makgadikgadi Pans National Park in Botswana. MScdissertation, University of Natal, Durban.

20. Fijn N (2013) Living with crocodiles: engagement with a powerful reptilian being. Animal studies journal 2(2): 1-27.

21. Gruen RL (2009) Crocodile attacks in Australia: challenges for injury prevention and trauma care. World journal of surgery 33(8): 15541561.

22. Food and Agricultural Organization of the United Nations (2013) Implementing improved tenure governance in fisheries.

23. Musambachime MC (1987) The fate of the Nile crocodile in African waterways. African Affairs 343(88): 197-207.

24. Whitlow R (1990) Conservation status of wetlands in Zimbabwe: past and present. GeoJournal 20(3): 191-202.

25. Food and Agricultural Organization of the United Nations (2010) Managing the conflicts between people and lion. Rome: The Organization.

26. Virtanen P (2005) Community based natural resources management in Mozambique: A critical review of the concept's applicability at local level. Sustainable development 13: 1-12.

27. BoudreauxK, Nelson F (2011) Community conservation in Namibia: Empowering the poor with property rights. Economic affairs 31(2): 17-24.

28. Madhusudan MD (2003) Living amidst large wildlife: livestock and crop depredation bylarge mammals in the interior villages of Bhadra Tiger Reserve, South India. Environmental management 31(4): 466475.

29. Ogada MO, Woodroffe R, Oguge NO, Frank LG (2003) Limiting depredation by African carnivores: the role of livestock husbandry. Conservation biology 17(6): 1521-1530.
30. Crocodile Specialist Group (CSG) (2011) January 2011 - March 2011 Newsletter, Volume 30(1).

31. Parks and Wildlife Service of the Northern Territory (PWSNT) (2012) Management programme for the saltwater crocodile in the Northern Territory of Australia 2012- 2014. Palmerston, NT: NT Department of Natural Resources, Environment and the Arts.

32. Campell HA, Watts ME, Sullivan S, Read MA, Choukroun S, et al. (2010) Estuarine crocodiles ride surface currents to facililate long-distance travel. Journal of ecology 79(5): 955-964.

33. Treves A, Karanth KU (2003) Human-carnivore conflict and perspectives on carnivore Management worldwide. Conservation biology 17(6): 1491-1499.

34. Purchase GK, Vhurumuku G (2005) Evaluation of a wild-wild translocation of cheetah (Acinonyxjubatus) from private land to Matusadonha National Park, Zimbabwe (1994-2005). Harare, Zumbabwe: Zambezi Society.

35. Griffiths B, Scott MJ, Carpenter JW, Reed C (1989) Translocation as a species conservation tool: status and strategy. Science 245(4917): 477-480.

36. Aust P W (2009) The ecology, conservation and management of Nile crocodiles Crocodylusniloticusin a human dominated landscape. Imperial College London Division of Biology, UK.

37. CITES (2012) Appendices I, II and III.

38. Karama, Australia: IUCN, World Conservation Union, Species Survival Commission.

39. Fergusson RA (2010) Nile crocodile, Crocodylusniloticus. In IUCN/ SCCCrocodile Specialist Group: crocodiles status, survey and conservation action planp. 84-89.

40.IUCN/UNEP/WWF (1991) Caring for the Earth, A Strategy for Sustainable Living. (R. Prescott-Allen, writer). Gland, Switzerland.

41. Lang JW, Andrews HV (1994) Temperature-dependent sex determination in crocodilians. Journal of experimental zoology 270(1): 28-44.

42. Le Bel S, Murwira A, Mukamuri B, Czudek R, Taylor R, et al. (2010) Human wildlife conflicts in Southern Africa: riding the whirl wind in Mozambique and in Zimbabwe. In Pujol JL (ed.); The importance of biological interactions in the study of biodiversity. Rijeka, Croatia: Intech.

43. Whitaker N (2007) Survey of Human/Crocodile Conflict in India, Maharashtra. Madras Crocodile Trust

44. Woodward AR, DN David, RL Degner (1993) The rise and fall of crocodile skin prices: Where do we go from here? InProceedings of the $2^{\text {nd }}$ RegionalMeeting of the CSG, Darwin, Australia. IUCN, Gland, Switzerland. 
This work is licensed under Creative Commons Attribution 4.0 License

DOI: 10.19080/IJESNR.2018.13.555856
Your next submission with Juniper Publishers will reach you the below assets

- Quality Editorial service

- Swift Peer Review

- Reprints availability

- E-prints Service

- Manuscript Podcast for convenient understanding

- Global attainment for your research

- Manuscript accessibility in different formats

( Pdf, E-pub, Full Text, Audio)

- Unceasing customer service

Track the below URL for one-step submission https://juniperpublishers.com/online-submission.php 